\title{
MICROBIOLOGICAL QUALITY AND SAFETY OF SKIPJACK TUNA LOINS (KATSUWONUS PELAMIS) INTENTED FOR CANNING
}

\author{
Francesco Casalinuovoํ, Donatella Brindisi ${ }^{2}$, Paola Rippa ${ }^{1}$, Carlotta Ceniti ${ }^{3}$, \\ Lucia Ciambrone ${ }^{1}$, Rosanna Musarella ${ }^{1}$, Nicola Costanzo ${ }^{3}$ \\ ${ }^{1}$ Institute for Experimental Veterinary Medicine of Southern Italy, Viale Crotone \\ 88100 Catanzaro, Italy \\ ${ }^{2}$ Quality Manager Intertonno Srl, Zona Industriale Lotti 20/21 \\ 89843 Maierato (VV), Italy \\ ${ }^{3}$ Department of Health Sciences, Magna Graecia University, Viale Europa - Loc. \\ Germaneto Edificio delle Bioscienze 88100 - Catanzaro (CZ), Italy
}

Received 9 May 2017; Received in revised form 30 August 2017; Accepted 14 September 2017

\begin{abstract}
Tuna is a food widely consumed fresh and canned as well. After catching and filleting, a pre-cooking step is normally followed by freezing and shipping to canning industry as loins. The aim of this paper was to assess the microbiological quality and safety of tuna loins ( 50 samples) imported by an Italian canned tuna producer from two different FAO fishing areas. Total bacterial count (TBC), Coliforms, Enterobacteriaceae, Escherichia coli, Listeria monocytogenes, Salmonella, Staphylococcus aureus, Vibrio parahaemolyticus, Vibrio cholera, $\mathrm{pH}$ measurement, S. aureus enterotoxin and histamine levels were evaluated. Significant differences were evidenced for TBC, Enterobacteriaceae, E. coli, Coliforms and $\mathrm{pH}$ between fishing areas. Staphylococcus aureus was detected in all the samples tested at 1 to 3 Log cfu/g; Staphylococcus warneri, S. saprophyticus, S. epidermidis, S. hominis, S. intermedius, S. vitulinus and S. sciuri were also identified. Listeria monocytogenes, Salmonella, Vibrio parahaemolyticus, Vibrio cholera and Staphylococcus aureus enterotoxin were not detected. Histamine ranged between 0 to $5 \mathrm{mg} / \mathrm{kg}$. The tuna loins analysed in this paper have to be considered safe; staphylococci presence represents a possible concern and has to been taken in account when risk analysis is carried out.
\end{abstract}

Key words: tuna loins, Katsuwonus pelamis, canned tuna, Staphylococcus aureus, histamine

\section{INTRODUCTION}

Tuna is a salt water fish belonging to the tribe Thunnini, a part of the Scombridae family. Normally the name tuna encompasses more than 50 species; of which 5 (yellowfin Thunnus albacares, bigeye Thunnus obesus, bluefin Thunnus thynnus, albacore Thunnus alalunga, and

Corresponding author: Dr. Nicola Costanzo, $\mathrm{PhD}$

E-mail address: costanzo.nic@unicz.it

Present address: Department of Health Sciences, Magna Graecia

University, Viale Europa - Loc. Germaneto Edificio delle Bioscienze

88100 - Catanzaro (CZ), Italy

Phone: +39.0961 .3694203$

Copyright: (C) 2017 Casalinuovo F. This is an open-access article published under the terms of the Creative Commons Attribution License which permits unrestricted use, distribution, and reproduction in any medium, provided the original author and source are credited.

Competing Interests: The authors have declared that no competing interests exist.

Available Online First: 23 November 2017

Published on: 15 March 2018

https://doi.org/10.1515/macvetrev-2017-0028 skipjack Katsuwonus pelamis) are important to feed a global supply chain in which the European Union represents the primary market (10). Widely consumed worldwide as fresh or canned (2), tuna is caught in all the major oceans (15). After harvest it is normally eviscerated, steam cooked (precooking) and chilled to facilitate the cutting and the separation (cleaning) of the bones and skin (13). The light meat, obtained from the cleaning step, can be directly canned or frozen in plastic films vacuum packed (loins) and then shipped worldwide to producers, where it is thawed and canned.

Considering that tuna fish, like other scombroid fish, is commonly associated with cases and outbreaks of histamine intoxication, the precooking step is important for reducing bacterial contamination, in particular Gram-negative bacteria responsible for histamine production. 
Additionally, since humans represent the first reservoir of Staphylococcus aureus (8), handling and manipulation during the "cleaning" step may contaminate tuna. Furthermore, frozen storage can be carried on for a long time before the loins are used by the industry, whereas Staphylococcus aureus has been demonstrated to persist in frozen tuna loins at $-20^{\circ} \mathrm{C}$ for 4 weeks and to rapidly increase population up to $3 \mathrm{Log} \mathrm{cfu} / \mathrm{g}$ when thawed (17). Enterotoxin, a single thermostable chain protein, normally produced when Staphylococcus aureus reaches 5-6 Log cfu/g (14), is able to resist the canning process therefore this hazard has to be considered in risk assessment.

The aim of this work is to assess the microbiological quality and safety of precooked tuna loins imported by a canned tuna producer in the Calabria region (Italy) from two different fishing areas, focusing on Staphylococcus aureus enterotoxin and histamine.

\section{MATERIAL AND METHODS}

Fifty samples of frozen precooked loins of skipjack tuna (Katsuwonus pelamis), were obtained from a canning plant. 38 were from fishing area $n^{\circ} 71$ and 12 from fishing area $n^{\circ} 87$ of the Food and Agriculture Organization of the United Nations (FAO). Two hundred grams of tuna meat were aseptically sampled after thawing overnight (12-14 hours) in refrigerator at $7^{\circ} \mathrm{C}$, and the samples were prepared within $1 \mathrm{~h}$. Samples preparation for microbiological analysis was made according to UNI EN ISO 6887-3:2004. On every sample the following analyses were carried out. Total bacterial count (TBC) was evaluated according to UNI EN ISO 4833-1:2013 using Plate Count Agar (Oxoid, Hampshire, UK) as culture medium incubating plates for $24 \mathrm{~h}$ at $30^{\circ} \mathrm{C}$. Coliforms and Enterobacteriaceae were enumerated on Violet Red Bile Agar (Oxoid, Hampshire, UK), according to ISO 4832-2006 and ISO 21528-2:2004.

Enumeration of beta-glucuronidase-positive Escherichia coli was performed according to UNI EN ISO 16649-1:2003; suspect isolates were confirmed by negative oxidase reaction (Oxoid, Hampshire, UK) and in positive indole reaction (Oxoid, Hampshire, UK).

Detection of Listeria monocytogenes was assessed according to UNI EN ISO 112901:2005; Listeria monocytogenes like-colonies were tested by Vitek2 System in accordance to the manufacturer's instructions (bioMérieux SA, Marcy-l'Etoile, France).

Detection of Salmonella was done in accordance with ISO 6579:09.2006; colonies were biochemically tested by using Vitek 2 System in accordance with the manufacturer's instructions (bioMérieux SA, Marcy-l'Etoile, France).

Enumeration of Staphylococcus aureus (UNI EN ISO 6888 - 1:2004) was carried out after dilution in peptone water (Oxoid, Hampshire, UK) and using Baird-Parker Medium (Oxoid, Hampshire, UK) for culturing. The identification of suspect colonies was performed by the detection of coagulase (Denka Seiken, Tokyo, Japan) and confirmation using ViTek (bioMérieux SA, Marcyl'Etoile, France).

Vibrio parahaemolyticus and Vibrio cholera were researched following ISO/TS 21872-1:2007; biochemical identification was carried out using Vitek2 (bioMérieux SA, Marcy-l'Etoile, France).

$\mathrm{pH}$ measurement was performed as reported by Kyrana (12) using a 5:1, water:fish homogenate and a glass electrode at $20^{\circ} \mathrm{C}$ (PCE instruments UK).

Staphylococcus aureus enterotoxin presence was assessed using miniVidas ${ }^{\circledR}$ (BioMèrieux, France) according to manufacturers instruction.

Histamine levels were evaluated using a colorimetric assay method with a commercial rapid histamine test kit (RIDA $®$ QUICK Histamine from R-Biopharm AG, Darmstadt, Germany) in $50 \mathrm{~g}$ of fish muscle according to the manufacturer's instruction.

All bacterial counts were analysed in triplicate; results are the means of three determinations and expressed as Log values for statistical analysis. To asses if the samples coming from the two fishing areas were different a $t$ test was performed. Furthermore, the correlation between $\mathrm{pH}$ and microbiological parameters was analysed by linear regression. The statistical software GraphPad Prism version 7.00 for Windows (GraphPad Software, La Jolla California USA, (www.graphpad.com) was used.

\section{RESULTS}

The total bacterial count ranged from 2,94 to 6,04 Log cfu/g for samples from FAO fishing area 71 and from 4,08 to 7,26 for samples from FAO fishing area 87. Results are showed in Fig 1. 
Total Bacterial Counts

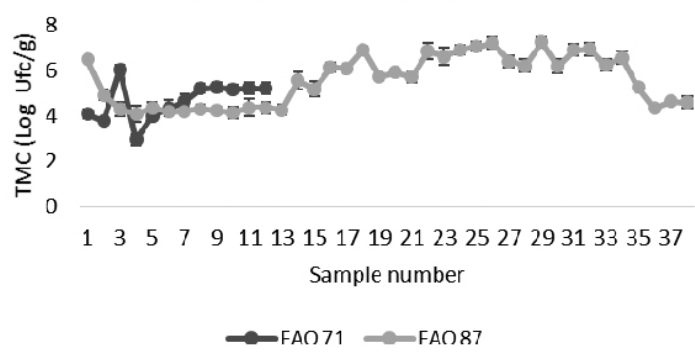

Figure 1. Total bacterial count(TBC) of microorganisms in tuna loins from two different FAO fishing areas

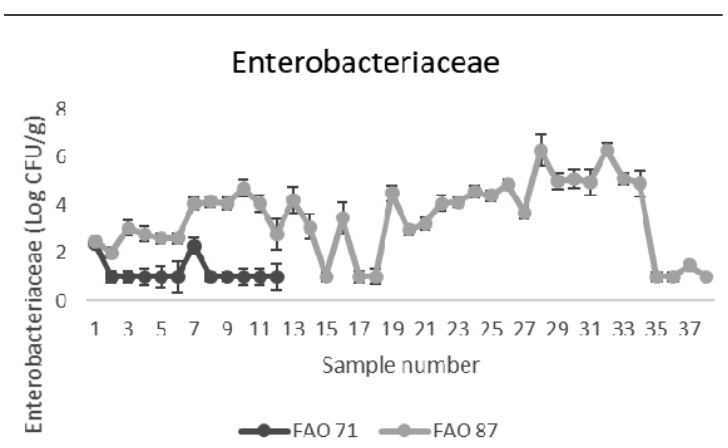

Figure 3. Enterobacteriaceae in tuna loins from two different FAO fishing areas

Results for coliforms, Escherichia coli and Enterobacteriaceae are reported in Fig. 2, 3 and 4 respectively.

Total bacterial count, Coliforms, E. coli and Enterobacteriaceae were statistically different between the fishing areas $(\mathrm{p}<0,05)$.

A positive correlation was evidenced between $\mathrm{pH}$ and $\mathrm{TBC}(\mathrm{r}=0,3831 \mathrm{p}<0,05)$, between $\mathrm{pH}$ and coliforms $(\mathrm{r}=0,7834 \mathrm{p}<0,05), \mathrm{pH}$ and $E$. coli $(\mathrm{r}=0,6962 \mathrm{p}<0,05)$ and between $\mathrm{pH}$ and Enterobacteriaceae $(\mathrm{r}=0,7249 ; \mathrm{p}<0,05)$.

Staphylococcus aureus was evidenced in 45 samples below $2 \mathrm{Log} \mathrm{cfu} / \mathrm{g}$ and in 5 samples, from FAO fishing area 71, exceeding $3 \mathrm{Log} \mathrm{cfu} / \mathrm{g}$. A total of 7 staphylococcal species were also isolated from 9 samples; the most frequent species was $S$. warneri (3 isolates), followed by $S$. saprophyticus ( 2 isolates), S. epidermidis (1 isolate), S. hominis (1 isolate), S. intermedius (1 isolate), S. vitulinus and S. sciuri (1 isolate). Staphylococcus aureus enterotoxin was not evidenced in any of the samples tested.

Listeria monocytogenes, Salmonella spp., Vibrio parahaemolyticus and Vibrio cholera were not detected in any of the samples tested.

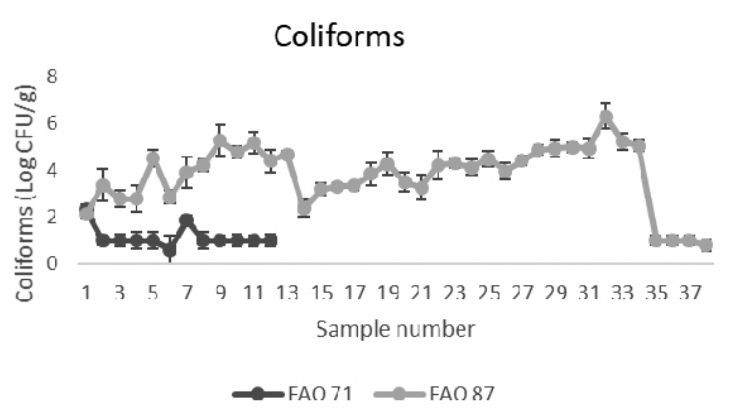

Figure 2. Coliforms in tuna loins from two different FAO fishing areas

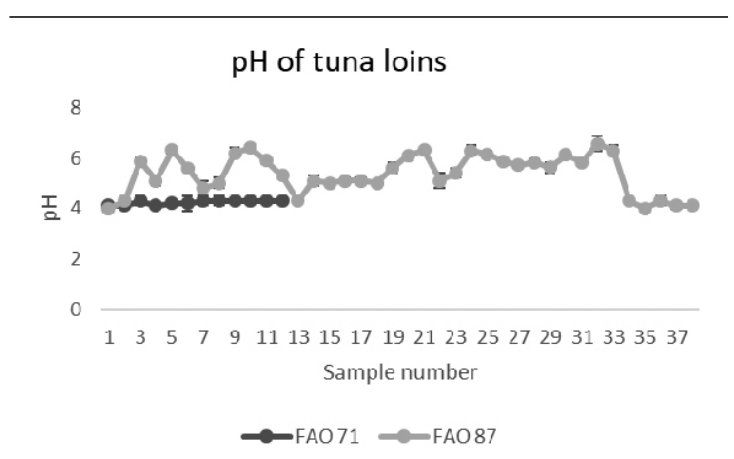

Figure 4. $\mathrm{pH}$ in tuna loins from two different FAO fishing areas

Histamine levels ranged between 0 to $5 \mathrm{mg} / \mathrm{kg}$; no differences were evidenced between harvesting areas.

\section{DISCUSSION}

The results of total bacterial count, Enterobacteriaceae and coliforms indicated a high contamination rate of tuna loins. In previous studies $\mathrm{Wu}$ and $\mathrm{Su}$ (17) reported that loins, chunk and flake of albacore and skipjack, analysed after thawing, had a total bacterial count ranging from 3,46 to $3,99 \mathrm{Log} \mathrm{cfu} / \mathrm{g}$. $\mathrm{pH}$ values, in tuna from the FAO 71 fishing area, are in agreement with previous studies (17) where a range from 5,60 to 5,61 was reported; on the other hand samples from FAO 87 fishing area had a statistically lower $\mathrm{pH}$. The difference in the bacteriological and $\mathrm{pH}$ values between fishing areas can be due to capture and post-capture practices used in the different FAO areas or to a temperature abuse before freezing (6).

The presence of Staphylococcus aureus in all the samples tested can be due to the manual handling of 
pre-cooked tuna loins prior to canning. Although contamination reached $3 \mathrm{log} \mathrm{cfu} / \mathrm{g}$ in 5 samples, enterotoxin production has been demonstrated at $27^{\circ} \mathrm{C}$, within $8 \mathrm{~h}$ in albacore and within 8 to $10 \mathrm{~h}$ in skipjack (11). Additionally Staphylococcus warneri, $S$. intermedius and $S$. sciuri has been demonstrated to produce enterotoxin $(1,4)$ and enterotoxins genes were evidenced in S. saprophyticus and S. hominis as reported in previous studies $(5,16)$. Even though European regulation did not lay down limits for staphylococci in fishery products, but only for shelled and shucked products of cooked crustaceans and molluscan shellfish, Staphylococcus spp., presence has to be taken into account when risk analysis of tuna product is carried out, since temperature abuse can allow bacteria reaching 5-6 $\log \mathrm{cfu} / \mathrm{g}$ value normally indicated as threshold for enterotoxin production $(3,9)$.

Commission Regulation (2073/2005/EC) on microbiological criteria for foodstuff and its amendments (Regulation 1441/2007/EC and Regulation 365/2010/EC) lays down food safety criteria for histamine in fishery products for fish species (Scombridae, Clupeidae, Engraulidae, Coryfenidae, Pomatomidae, Scombresosidae) associated with a high amount of histidine between $100 \mathrm{mg} / \mathrm{kg}$ (m) and $200 \mathrm{mg} / \mathrm{kg}$ (M) and for fishery products which have undergone enzyme maturation treatment in brine, manufactured from fish species associated with a high amount of histidine between $200 \mathrm{mg} / \mathrm{kg}(\mathrm{m})$ and $400 \mathrm{mg} / \mathrm{kg}(\mathrm{M})$. In addition, Regulation 853/2004/EC lays down specific hygiene rules for food of animal origin, providing a possibility to set freshness criteria and limits for fishery products with regards to histamine and place the responsibility on food business operators to ensure that limits with regard to histamine are not exceeded in the context of health standards for these products. Histamine fish poisoning still represents the main hazard for canned tuna since no available method of preparation, including freezing, canning and smoking, is able to destroy the causative toxin (7). Our results, far from the EU limits, showed the safety of the analysed tuna loins.

For both histamine and enterotoxin, attention has to be paid to cold chain maintenance especially after thawing and before canning.

\section{CONCLUSION}

Tuna loins analysed in this paper have to be considered safe; the pre-cook step, normally used in processing of tuna loins, was successful in reducing bacterial load, destroying pathogens and halting gram negative growth responsible for histamine production. The main concerns are represented by histamine and staphylococci presence: temperature used in the canning process can destroy all vegetative cells, but enterotoxin and histamine are able to resist canning temperature. Minimizing the time between thawing and canning can reduce risk to an acceptable level.

\section{CONFLICT OF INTEREST}

The authors declare that they have no potential conflict of interest with respect to the authorship and/or publication of this article.

\section{ACKNOWLEDGEMENT}

Special thanks to Dr Elonora Sarno for all advices and support.

\section{REFERENCES}

1. Becker, K., Keller, B., von Eiff, C., Brück, M., Lubritz, G., Etienne, J., Peters, G. (2001). Enterotoxigenic potential of Staphylococcus intermedius. Appl Environ Microbiol. 67, 5551-5557.

https://doi.org/10.1128/AEM.67.12.5551-5557.2001 PMid:11722906 PMCid:PMC93343

2. Catarci, C. (2005). The world tuna industry-an analysis of imports and prices, and of their combined impact on catches and tuna fishing capacity. In: W. Bayliff, J. I. Leiva Moreno, J. Majkowski (Eds.), Management of tuna fishing capacity: Conservation and socio-economics. (pp. 235-278). FAO, Roma, Italy.

3. Castillejo-Rodriguez, A. M., Gimeno, R.M.G., Cosano, G. Z., Alcala, E. B., Perez, M. R. R. (2002). Assessment of mathematical models for predicting Staphylococcus aureus growth in cooked meat products. J Food Prot. 65, 659-665.

https://doi.org/10.4315/0362-028X-65.4.659 PMid:11952215

4. Chou, C. C., Chen, L. F. (1997). Enterotoxin production by Staphylococcus warneri CCRC 12929, a coagulase-negative strain. J Food Prot. 8, 923-927.

https://doi.org/10.4315/0362-028X-60.8.923 
5. Cunha, M. L. R. S., Calsolari, R.A., Araújo, Jr. J. P. (2007). Detection of enterotoxin and toxic shock syndrome toxin 1 genes in Staphylococcus, with emphasis on coagulase-negative staphylococci. Microbiology and Immunology 51, 381-390. https://doi.org/10.1111/j.1348-0421.2007.tb03925.x

6. Economou, V., Brett, M. M., Papadopoulou, C., Frillingos, S., Nichols, T. (2007). Changes in histamine and microbiological analyses in fresh and frozen tuna muscle during temperature abuse. Food Addit Contam. 8, 820-832.

https://doi.org/10.1080/02652030701278321

PMid:17613069

7. Etkind P., Wilson, M.E., Gallagher, K., Cournoyer J. (1987). Bluefish-associated scombroid poisoning. An example of the expanding spectrum of food poisoning from seafood. J Am Med Assoc. 258 (23): 3409-3410.

https://doi.org/10.1001/jama.1987.03400230069034 PMid:3682140

8. FDA (2011). Fish and fishery products hazards and controls guidance (4th ed.). Center for Food Safety \& Applied Nutrition http://www.fda.gov/food/ guidanceregulation/guidancedocumentsregulator yinformation/seafood/ucm2018426.htm Accessed 23.09.2016

9. Fujikawa, H., Morozumi, S. (2006). Modeling Staphylococcus aureus growth and enterotoxin production in milk. Food Microbiol. 23, 260-267.

https://doi.org/10.1016/j.fm.2005.04.005

PMid:16943012

10. Hamilton, A., Lewis, A., McCoy, M. A., Havice, E., Campling, L. (2011). Market and industry dynamics in the global tuna supply chain. Forum Fisheries Agency Honiara (Solomon Islands).

11. Kataoka, A., Enache, E., Napier, C., Hayman, M., Weddig, L. (2016). Effect of storage temperature on the outgrowth and toxin production of Staphylococcus aureus in freeze-thawed precooked tuna meat. J Food Prot. 79, 620-627.

https://doi.org/10.4315/0362-028X.JFP-15-439

PMid:27052867
12. Kyrana, V. R., Lougovious, V. P. (2002). Sensory, chemical and microbiological assessment of farm raised European sea-bass (Dicentrarchus Labrax) stored in melting ice. Int J Food Sci Tech. 37, 319328.

https://doi.org/10.1046/j.1365-2621.2002.00572.x

13. Lassen, S. (1965). Tuna canning and the preservation of the raw material through brine refrigeration. In: G. Borgstrom (Ed.), Fish as Food. Vol IV (pp. 207-246). Cambridge Academic Press Inc. https://doi.org/10.1016/B978-0-12-395572-2.50009-1

14. Le Loir, Y., Baron F., Gautier M. (2003). Staphylococcus aureus and food poisoning. Genet Mol Res. 2, 63-76. PMid:12917803

15. Miyake, P.M., Miyabe, N., Nakano, H. (2004). Historical trends of tuna catches in the world. FAO Fisheries Technical Paper

16. Rall, V. L., Sforcin, J. M., de Deus, M. F., de Sousa, D. C., Camargo C. H., Godinho, N. C., Galindo, L. A., Soares, T. C., Araújo J. P. Jr. (2010). Polymerase chain reaction detection of enterotoxins genes in coagulase-negative staphylococci isolated from Brazilian Minas cheese. Foodborne Pathog Dis. 7, 1121-1123.

https://doi.org/10.1089/fpd.2009.0478

PMid:20528174

17. Wu, X., Su, Y. C. (2014). Effects of frozen storage on survival of Staphylococcus aureus and enterotoxin production in precooked tuna meat. J. Food Sci. 79, 1554-1559. https://doi.org/10.1111/1750-3841.12530 PMid:25039601 